\title{
THE EFFECTIVENESS OF INTERVENTION PROGRAMS: CHANGING PERSPECTIVES OF PARENTS AGAINST THE FINAL RESULTS OF LEARNING IN KINDERGARTEN
}

\author{
Nila Fitria ${ }^{1}$, Nurfadilah \\ University of Al-Azhar Indonesia
}

\begin{abstract}
The purpose of this study is to test the effectiveness of parenting seminars to change the perspective of the parents towards the end results of learning in kindergarten. This research was conducted with quantitative methods with this type of survey research. Questionnaire in this tudy was made in the form of open ended questions. Overall it was concluded that at the time of pre test $37 \%$ still expect read write count (calistung) programs conducted in kindergartens. While 63\% of respondents change of perspective, they no longer prioritize read write count (calistung) or cognitive aspects as the final results of the study children in kindergarten. parental perspective changes include the establishment of character, social skills, and creative.
\end{abstract}

Keyword: Intervention Programs, Parents Perspectives, Kindergarten

\begin{abstract}
Abstrak: Tujuan penelitian ini adalah untuk menguji keefektifan parenting seminar untuk mengubah perspektif orang tua terhadap hasil akhir pembelajaran di taman kanak-kanak. Penelitian ini dilakukan dengan metode kuantitatif dengan jenis penelitian survei. Kuesioner dalam putusan ini dibuat dalam bentuk pertanyaan terbuka. Secara keseluruhan disimpulkan bahwa pada saat tes awal 37\% masih mengharapkan program baca tulis (calistung) dilakukan di taman kanak-kanak. Sementara 63\% responden mengubah perspektif, mereka tidak lagi memprioritaskan membaca menulis hitungan (calistung) atau aspek kognitif sebagai hasil akhir dari studi anak-anak di taman kanak-kanak. perubahan perspektif orang tua termasuk pembentukan karakter, keterampilan sosial, dan kreatif.

Kata Kunci: Program Intervensi, Perspektif Orangtua, Taman kanak-kanak
\end{abstract}

\section{INTRODUCTION}

The majority of scholars of education realized that the low competitiveness of the nation of Indonesia caused a learning orientation is cognitive attitude and mastery of skills so graduates education Indonesia low. Ironically at a time when basic education until College started to realize the importance of established attitudes and skills and gradually begin to reduce cognitive orientation, but at the same time early childhood education and started orientating in cognitive learning read write count (calistung).

Grand tour results in some early childhood education Jabodetabek pointed out that the need to read and write capability as soon as possible before entering elementary school has an impact on the orientation of learning in reading, writing and arithmetic in the early childhood education. learn through play on the early childhood education and the more difficult because the parents only saw an increase in learning through 33 March 2011, and consider playing for other development tasks such as developing the cognitive and emotional language, social, moral religion and art have not learned but play purely they consider can be done outside of school (early childhood education). Understanding learning for parents is

\footnotetext{
'University of Al-Azhar Indonesia, Email: nilafitria@uai.ac.id
} 
when teachers teach reading and writing directly to the child. The results of the interviews with the teachers also noted that parents often admonish teachers so soon taught read write count (calistung) when conducting the activity of playing although the goal for teaching read write count (calistung) through play.

Early childhood is the golden period to for children and is the right momentum in optimizing all the potential of integrative holistic basis. This golden period will not be repeated because it's this momentum must not be skipped so that the optimization potential of children can be developed optimally. Optimization of all potential child believed to be impacting on advanced education of the child. one of the tasks of the task of optimizing early childhood education educator child development good cognitive, language, social, emotional, moral, religious, or arts. read write count (calistung)child's learning orientation is not only not yet correspond to the tasks of development but other potential development through play is overlooked when all the tasks of development must be observed so that the lives of growing in a balanced way.

According to Bruner in Riley (2004, p. 10-11) children are gradually being able to know the world through three stages, namely: (1) the enactive representation (2) iconic representation, and symbolic representation. First, enactive representation i.e. stages of children's shows to think only by way of the second action, iconic representation i.e. children have started to be able to think in a way describe though without seeing the actual object. Third, symbolic representation, namely children have been able to think in the form of a symbol (e.g., speaking and writing). This study showed that read write count (calistung) emphasis on direct experience or iconic with the help of an adult.

Children start burdened with duties outside of the ability and duty of its development but according to Froebel in Makrides (2003) children learn well when the real matter manipulation, guided by an adult. Thus, it can be said that it is the duty of the teacher to organize learning activities and guides the behavior of children through play activities. Of all the theories of play which has been said by experts on play and early childhood can be summed up as follows: (1) play is a natural activity for early childhood learning, (2) the role of adults is to organize environmental play and activities encourage berekplorasi with active, and (3) the role of adults is to guide children in a learning environment.

On the Government Regulation No. 17 year 2010, article 69 paragraph 5, said that the reception of the students of class one (1) SD/MI or other forms of equal is not based on the results of a test of the ability of reading, writing, and arithmetic, or other tests. However this policy look ineffective as evidenced by the existence of public and private primary school which makes the ability of child read write count (calistung)as a prerequisite of the incoming SD. as time goes by, the orientation of the read write count (calistung) in early childhood education and not unstoppable and guidance Learn (bimbel) read write count (calistung)growing rapidly because of the visible phenomenon of parents who prefer bimbel read write count (calistung)than early childhood education institutions by reason of cost and time efficiency. This is supported by data obtained from Kemdikbud 2013 education statistics Centre, which indicating that from year to year an increase in the participation age early childhood education incoming SD less than 7 years from year to year was further increased.

As for the problem of this research is: is the intervention program parents in the form of seminar effective to change the perspective of the parents towards the end results of learning in kindergarten?.As for the purpose of this study is to test the 
effectiveness of parenting seminars to change the perspective of the parents towards the end results of learning in kindergarten

\section{LITERATURE REVIEW}

This chapter discusses the terms used in the research and study of the theory associated with this research.

\section{Perspectives Of Early Childhood Learning}

Learning in early childhood has been established in a curriculum that was developed in accordance with the level of development of the child. However, in the implementation of the curriculum depends greatly on educators and parents against the needs of graduates of the early childhood education (kindergarten) in towards the primary school.

Feeney (2006, p. 338) suggests that early childhood will learn well and is easy to understand when the information displayed in a way that is holistic, involving the whole of her senses, body and mind simultaneously. This is in line with that put forth by Bredekamp and Rosegrant in Charlesworth (2006, p. 08), about the cycle of learning in early childhood is composed of: (1) awareness, a consciousness of the wide top of objects, persons, or events the concept developed from experience; (2) exploration, namely construction of meaning through the experience of self knowledge the motor against the objects, people, events or concepts; (3) the inquiry, i.e. the child compares the construction with the culture, habits, known, general conclusions based on something similar to that performed by an adult; and (4) utilization, that the child can apply and use the understanding in new situations and settings.

Early childhood education and meant to prepare children entering primary school then for easy entering school according to Nixon and Aldwinckle (1997, p. 166), namely languages, skills, personal/social skills, maths and physical skills. The necessary language skills, among others; (1) speaking to others about objects and events that are known, (2) answering and asking simple question, (3) make needs known, (4) follow the instructions simple, (5) the use of books for pleasure or to see the pictures, (6) identify pictures in books, magazines, or on television or video, (8) using various objects (pens, pencils, textas, brushes and so on) to draw, scribble or write, and (9) were singing songs known. In the meantime the necessary math skills are; (1) getting to know the numbers that can be used to count, (2) use words like all, much, much more than, less than, (3) identify the objects in different groups, (4) notice a difference in form, (5) distinguish between upper and lower, above and below, in front and behind, as well as day and night.

\section{The Program Intervention}

An action that produces change or attempt to change individual, population, or organization that is the subject of the evaluation referred to as intervention (Øvretveit,1998). This intervention aims to make a change and make a change in someone's life (Øvretveit,1998). Forms of intervention undertaken in this research is parenting education in the form of seminars. Since the Directorate of construction education family was formed, organizing the parenting education program is thriving, both in number as well as its shape. Those programs, in general have different targets, there is a which aims to improve one aspect or a combination of knowledge, skills, attitudes, a means to gain social support, parental empowerment (or for Martin \& Colbert, 1997). The achievement of these goals is done with a variety of ways, packaging information that uniquely with different time allocation because there are indeed many ways to be successful parents for 
growing hibiscus conduces child the optimal.

\section{RESEARCH METHODOLOGY Types Of Research}

This research was conducted with quantitative methods with this type of survey research. Questionnaire in this tudy was made in the form of open ended questions

\section{Research Subject}

This is the entire research population parents EARLY CHILDHOOD institutions in building the Foundation "ABC" in Bogor, West Java.

\section{The Sample Withdrawal Techniques}

Sample withdrawal technique on research is purposive sampling because it is chosen based on the identification of problems in the population.

\section{Research Tool}

This research use research tools in the form of a questionnaire regarding the "end result after graduating kindergarten child's learning" and filled out by parents who attended the seminar at the time before and after the seminar.

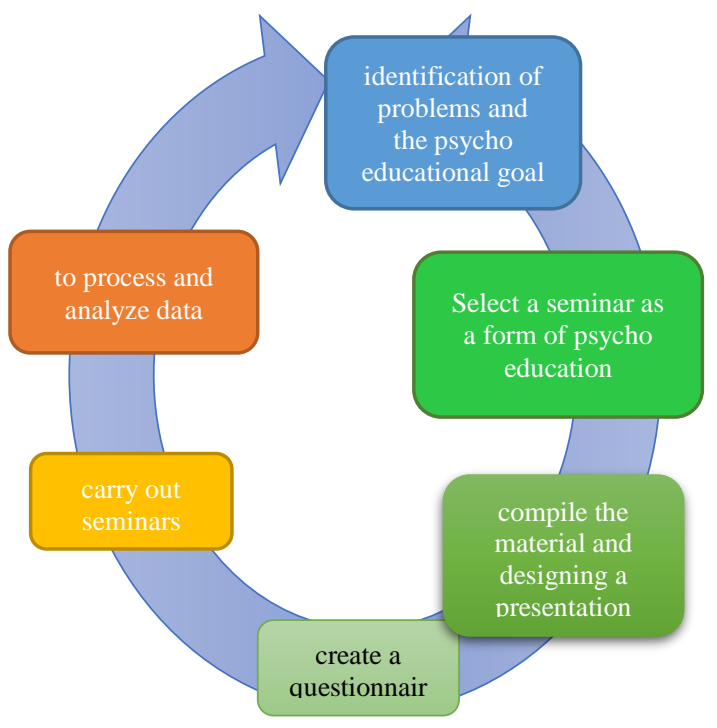

Data Processing Techniques

Processing of data in this study using a descriptive analysis, namely the emphasis on analysis data and discussion of the subject by presenting data systematically and not conclude the results of the research (Priyatno, 2008).

\section{Procedure Research}

Outline the procedure this research was conducted as follows:

Seminars are conducted using the method of lecture and question and answer. After the participants fill out questionnaires, participants shared read write count (calistung)seminar material on early childhood. This material referable for them to recall the importance of stimulation of development of children on all aspects of child development. In addition to the parents, the teachers were also given material reinforcement about reading and math for beginning early childhood in the form of Focus Group Discussion (FGD) in order to follow up on the results of the seminar together with the parent.

\section{RESULTS}

Seminar held at the host in the Hall of the mosque, which is located on the Ciremai, Warung Jambu, Bogor. The total number of respondents to this survey was 131 people. But data that can be processed is 87 people, because there is a complete lack of data loaded. The children who attended these schools is the orphans and disadvantaged children so that they do not charge for educated, ranging from early childhood education until high school. Generally the parents working as drivers, hawkers, scavenger, carpenters, laborers, security, vending, gado-gado seller, a washerwoman, and others.

Of the 87 parent who returns the pre test and post test, then it can be seen there are $63 \%$ had changed his perspective against the results of the study at a kindergarten. $63 \%$ of parents, changes in learning outcomes include the establishment of characters such as discipline, brave, confident, and independent. In addition parents also 
expect social skills possessed by the child such as socialization and able to cooperate. Another thing to expect parents i.e. child has creativity in sharing activity).

\section{DISCUSSIONS}

The research results obtained from an average score of $63 \%$ of the respondents revealed that change of perspective, they no longer prioritize read write count (calistung) or cognitive aspects of it as the ultimate outcome of learning in kindergarten children. In addition, the country as well as elementary school private has also implemented the test read write count (calistung) as conditions of admission the SD. this fact contrary to government regulations No. 17 year 2010, article 69 paragraph 5, which States that the acceptance of the students of class one (1) SD/MI or other forms equal is not based on the results of a test of the ability of reading, writing, and arithmetic, or other tests.

If the orientation of the child's learning focused on the cognitive aspect alone hence the creation of the Foundation of early education is not optimal. This understanding is not only required by early childhood education teacher but also by parents and other stakeholders.

Thus, it can be said that the intervention in the form of seminar effective enough to change the perspective of the parents towards the end results of learning in kindergarten

\section{CONCLUSIONS}

Overall it was concluded that at the time of pre test $37 \%$ still expect read write count (calistung) programs conducted in kindergartens. While $63 \%$ of respondents change of perspective, they no longer prioritize read write count (calistung) or cognitive aspects as the final results of the study children in kindergarten. parental perspective changes include the establishment of character, social skills, and creative.

\section{REFERENCES}

Charlesworth, R. (2011). Experiences in math for young children. Cengage Learning.

Feeney, S., Moravcik, E., Nolte, S., \& Christensen, D. (2006). Who am I in the lives of children?: An introduction to early childhood education. Pearson/Merrill/Prentice Hall.

Martin, Carole. Karen E Colbert \& E. (1997), Parenting: A life Span Perspective. United States of America. Mc Graw Hill.

Makrides, M., Crowther, C. A., Gibson, R. A., Gibson, R. S., \& Skeaff, C. M. (2003). Efficacy and tolerability of low-dose iron supplements during pregnancy: a randomized controlled trial. The American journal of clinical nutrition, 78(1), 145-153.

Nixon, D. \& Aldwinckle, M. (1997). Exploring child development from three to six years. Katoomba:Social Science Press

Øvretveit, J. (1998). Evaluating health interventions: an introduction to evaluation of health treatments, services, policies and organizational interventions.

McGraw-Hill International.

Priyatno, Dwi. (2008). Independent Learning SPSS for Data analysis and statistical tests. Yogyakarta: MediaKom.

Riley, A. W. (2004). Evidence that school-age children can self-report on their health. Ambulatory Pediatrics, 4(4), 371-376. 